\title{
Overgrowth of Human Synovial Cells Driven by the Human T Cell Leukemia Virus Type I tax Gene
}

\author{
Toshihiro Nakajima, Hiroyuki Aono, Tomoko Hasunuma, Kazuhiko Yamamoto, Ikuro Maruyama, * \\ Tetsuya Nosaka, ${ }^{*}$ Masakazu Hatanaka, ${ }^{*}$ and Kusuki Nishioka \\ Division of Rheumatology and Molecular Immunology, Institute of Medical Science, St. Marianna University, Kawasaki, Japan 216; \\ * Division of Clinical Investigation, Faculty of Medicine, Kagoshima University, Kagoshima, Japan 890; \\ and ${ }^{\ddagger}$ Institute for Virus Research, Kyoto University, Kyoto, Japan 606
}

\begin{abstract}
One of the salient pathological features of rheumatoid arthritis is synovial cell proliferation with bone erosion. Despite extensive investigation, the factors essential for synovial cell proliferation remain to be identified. Recent studies suggest that human $T$ cell leukemia virus type I (HTLV-I) may play an important role in synovial overgrowth observed in patients with one type of chronic inflammatory synovitis. In order to confirm and extend these observations, we have established synovial cell clones (SCCs) from three HTLV-I carriers who demonstrated synovial overgrowth but were otherwise asymptomatic. HTLVI proviral DNA randomly integrated into the cellular genome was present in 20-30\% of SCCs. The SCCs carrying HTLV-I proviral DNA and expressing the tax gene exhibited high levels of proliferative potential. HTLV-I was found to function as a transcriptional trans-activator in these SCCs. Moreover, transfection of the tax expression plasmid into SCCs resulted in the same phenotype of increased proliferation and cytokine expression as exhibited by HTLV-I provirus-carrying and tax-expressing SCCs. These data suggest that tax plays a critical role not only in leukemogenesis but also in synovial overgrowth in humans. (J. Clin. Invest. 1993. 92:186-193.) Key words: human $T$ cell leukemia virus type $I \cdot$ rheumatoid arthritis $\bullet$ synovial cell $\cdot$ synovial overgrowth $\bullet$ tax gene
\end{abstract}

\section{Introduction}

Human T cell leukemia virus type I (HTLV-I $)^{1}(1,2)$ is known as the causative agent of adult $T$ cell leukemia $(3,4)$ and is found to be closely associated with a nonmalignant neurologi-

Address reprint requests to Dr. Kusuki Nishioka, Division of Rheumatology and Molecular Immunology, Institute of Medical Science, St. Marianna University School of Medicine, 2-16-1 Sugao, Miyamae-ku, Kawasaki, Kanagawa 216, Japan.

Received for publication 24 September 1992 and in revised form 28 January 1993

1. Abbreviations used in this paper: ATL, adult T cell leukemia; CREB/ ATF, cAMP-responding element-binding protein/activating transforming factor; HAAP, HTLV-I-associated arthropathy; HTLV-I, human T cell leukemia type I; LM, ligand mediated; LTR, long terminal repeat; NGF, nerve growth factor; SCCs, synovial cell clones; TSP/ HAM, tropical spastic paraparesis or HTLV-I-associated myelopathy; $\mathrm{RT}$, reverse transcription.

J. Clin. Invest.

(C) The American Society for Clinical Investigation, Inc.

$0021-9738 / 93 / 07 / 186 / 08 \$ 2.00$

Volume 92 , July 1993, 186-193 cal disorder termed tropical spastic paraparesis or HTLV-I-associated myelopathy (TSP/HAM) $(5,6)$. Recently, a chronic inflammatory arthropathy was found in patients with chronic adult T cell leukemia (ATL) $(7,8)$ and TSP/HAM (9) and among HTLV-I carriers $(10,11)$. We have thus likened it to HTLV-I-associated arthropathy (HAAP) $(10,12)$. In the course of investigations on the relationship between HTLV-I infection and synovial cell proliferation, we found that IgM- as well as IgG-type anti-HTLV-I antibodies persist in the synovial fluid of affected joints but not in sera in patients with this arthropathy (8). We also reported the presence and expression of the proviral HTLV-I genome in non-T cell synovial cells of HAAP patients (13). Moreover, transgenic mice that carried and preferentially expressed the HTLV-I pX gene in the articular lesion had shown a synovial overgrowth resembling that seen in a patient with RA (14). These observations raise the possibility that integration of proviral HTLV-I DNA into synovial cells may play a central role in the pathogenesis of HAAP. We have attempted here to establish whether the synovial overgrowth of HAAP might result from HTLV-I integration. Our data indicate that HTLV-I tax expression causes synovial cell proliferation in humans. These findings provide important insights into the biological function of the HTLV-I tax gene.

\section{Methods}

Establishment of non-T cell synovial cell clones (SCCs) and detection of HTLV-I proviral DNA. Three patients with HAAP were examined in this study after obtaining their informed consent. Their clinical manifestations have already been described (11). The limiting dilution method was employed to establish non-T cell SCCs from these patients. Lymphocyte-depleted synovial cells were immediately prepared to prevent in vitro HTLV-I transmission as described $(13,15)$. Briefly, synovial tissues were obtained by biopsy from affected joints under arthroscopy. These tissues were minced into small pieces, washed three times in PBS, and treated with PBS- $0.25 \%$ trypsin for 20 min at $37^{\circ} \mathrm{C}$. These cells were then diluted to five cells per milliliter with the following culture medium: HAM F-12 medium (Gibco Laboratories, Grand Island NY) supplemented with $10 \% \mathrm{FCS}, 5 \times 10^{-5} \mathrm{M}$ 2-mercaptoethanol, $100 \mathrm{U} / \mathrm{ml}$ of penicillin, and $100 \mu \mathrm{g} / \mathrm{ml}$ of streptomycin ). Each $0.1 \mathrm{ml}$ of cell suspension was dispensed into four 96-well flat-bottomed culture plates $(0.5$ cells per well $)$. When the cell culture reached confluency (about $5 \times 10^{3}$ cells per well) or on the 60th day of culture, one half of the cells were harvested from each well and the genomic DNA isolated by SDS/proteinase $\mathrm{K}$ digestion and subsequent phenol and chloroform extraction. The PCR (16) was applied for the detection of proviral DNA. Briefly, we used two primer sets: one is specific for the HTLV-I pX region (SK-43, 5- ${ }^{7335}$ CGGATACCCATGCTACGTGT $^{7354}-3$; SK-44,5- ${ }^{7493}$ GAGCCGATAACGCGTCCATCG ${ }^{7473}-3$ ) (17); and the other is specific for human lymphocyte antigen (HLA DQ $\beta$ ) (GH28,5- ${ }^{24}$ CTCGGATTCGCATGTGCTACTTCA CCAAGC $^{45}$-3; GH29,5- ${ }^{245}$ GAGCTGCAGGTAGTTGTGTCTGCA$\left.\mathrm{CAC}^{227}-3\right)$ as an internal control (18). The reaction mixture $(50 \mu \mathrm{l})$ 
consisted of $25 \mathrm{ng}$ of DNA sample, $50 \mathrm{pmol}$ of each primer, $200 \mu \mathrm{mol}$ of each deoxynucleotide triphosphate, and $2.0 \mathrm{U}$ of Taq polymerase (Perkin-Elmer Cetus, Norwalk, CT). This mixture was subjected to 40 cycles of denaturation for $1 \mathrm{~min}$ at $94^{\circ} \mathrm{C}$, primer annealing for $2 \mathrm{~min}$ at $60^{\circ} \mathrm{C}$, and chain elongation for $3 \mathrm{~min}$ at $72^{\circ} \mathrm{C}$ using a DNA thermal cycler (Perkin-Elmer Cetus). One fifth of the amplified DNA was then separated by $1.5 \%$ agarose gel electrophoresis and visualized by ethidium bromide fluorostaining. We regarded the SCCs that exhibited positive amplification from both HTLV-I proviral DNA and HLA DQ $\beta$ as "integrated." Among the SSCs that were amplified, only HLA DQ $\beta$ was considered to be "nonintegrated SCCs." These results were reproducible and neither HTLV-I nor HLA DQ $\beta$ were observed in the "no DNA" samples that had been amplified without DNA as a negative control for each PCR reaction.

Colony formation assay. 1,000 cells each from the four kinds of SCCs (Fig. 1) were cultured in semisolid medium containing $0.33 \%$ agarose. After $14 \mathrm{~d}$ of culture, the number of colonies that consisted of $>10$ cells were counted under microscopy.

Detection of $c$-fos, $I L-1 \beta$, and $I L-6 m R N A$ under starvation conditions. $5 \times 10^{5}$ cells from individual SCCs were cultured under serumfree conditions for $48 \mathrm{~h}$ to exclude the effect of serum factors that can induce $c$-fos transcripts. At this point, the SCCs were harvested and total RNA was isolated using the acid guanidine thiocyanate-phenol/ chloroform method (19). After treatment with RNase-free DNase and quantification, 10 -fold titrated RNA ( $20 \mathrm{pg}-200 \mathrm{ng}$ ) was converted to cDNA by reverse transcriptase. The amplification procedure consisted of 35 cycles $\left(94^{\circ} \mathrm{C}\right.$ for $1 \mathrm{~min}, 62^{\circ} \mathrm{C}$ for $1 \mathrm{~min}, 72^{\circ} \mathrm{C}$ for $\left.1 \mathrm{~min}\right)$ with the following oligonucleotide primer sets: Fos 1 ( $5-^{889}$ ATGATGTTCTCGGGCTTCAACG ${ }^{910}$-3) and Fos 3 (5- ${ }^{1992}$ TCCTGTCATGGTCTTCACAACG $^{1971}-3$ ), specific for $c$-fos (GeneBank accession nos. K00650 and M16287); IL-1-1 (5-1561 GAAGCTGATGGCCCTAAACAGATG ${ }^{1584}$. 3 ) and IL-1-2 (5- ${ }^{4374}$ GGTGCATCGTGCACATAAGCCTCG $\left.{ }^{4351}-3\right)$, specific for IL-1 $\beta$ (GeneBank accession no. M15840); IL-6-1 (5${ }^{1396}$ GCGCCTTCGGTCCAGTTGCCTTCTC ${ }^{1420}-3$ ) and IL-6-2 (5${ }^{2673}$ CCTCTTTGCTGCTTTCACACATG ${ }^{2651}-3$ ), specific for IL-6 (GeneBank accession no. Y00081); and BAC1 (5- ${ }^{1417}$ AAGAGAGGCATCCTCACCCT $\left.{ }^{1490}-3\right)$ and BAC2 (5-2129 TACATGGCTGGGGTGTTGAA $^{2110}-3$ ), specific for $\beta$-actin (GeneBank accession nos. $\mathrm{X} 00351, \mathrm{~J} 00074$, and M10278). All the sequence numbers correspond to those of the GeneBank data base.

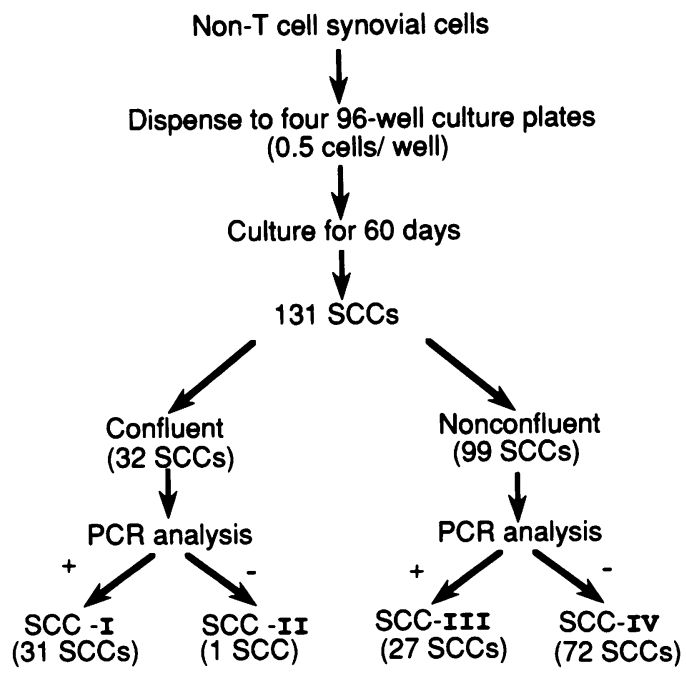

Figure 1. Scheme for SCC classification. Each SCC was cultured for $60 \mathrm{~d}$. On the 60 th day of culture, individual SCCs were separated into two types based on proliferative rates: those reaching confluency and those that did not. In addition, PCR analysis for the proviral HTLV-I pX region revealed which SCCs had proviral HTLV-I DNA $(+)$ and which did not $(-)$.
Study of the half-life of c-fos mRNA in individual SCCs. $1 \times 10^{4}$ cells per well of SCCs-I with or without $10 \%$ FCS and SCC-II with $10 \%$ FCS were cultured for $48 \mathrm{~h}$. Actinomycin-D $(5 \mu \mathrm{g} / \mathrm{ml})$ was then added to the cultures. Total RNA was recovered at the intervals of $0,60,120$, and $180 \mathrm{~min}$. Cell viabilities before RNA recovery were always $>90 \%$. $5 \%$ of the converted cDNAs were amplified with 5 'biotinylated Fos 1 and Fos 3 oligonucleotide primers. 20\% of the amplified products ( 10 $\mu \mathrm{l})$ were electrophoresed on a $6 \%$ polyacrylamide gel and transferred to Imobilon-S (MilliGen/ Biosearch, Burlington, MA). Transferred biotinylated products were visualized using the streptavidin/biotinylated alkaline phosphatase/chemiluminescent substrate system (Plex luminescent kit, MilliGene/Biosearch). Densitometry was performed on the autoradiograms and percent inhibition was expressed as (absorbance units at the indicated time divided by that at 0 time) $\times 100$, was plotted against time to estimate the half-life of $c$-fos mRNA.

Analysis of the mode of HTLV-I integration into SCCS-I by the modified ligand-mediated PCR (LM-PCR). We performed the modified LM-PCR $(20,21)$ in the following manner. Briefly, DNA obtained from each of six SCCs-I was completely digested with EcoRI and extended with the HTLV-I long terminal repeat (LTR) specific oligonucleotide primer, IP-1 (5- ${ }^{78}$ TTTCACTGGGAGGCTCTAAG $\left.{ }^{59}-3\right)$, by Sequenase Ver. 2 (U.S. Biochemical Corp., Cleveland, $\mathrm{OH}$ ) to create a blunt end which was then ligated with oligonucleotide linkers. Linkerligated DNA was amplified with IP-2 (5-49GATATTTGGGGCTCATGGTCA $^{29}$-3) specific for HTLV-I LTR and L1 (5-GCGGTGACCCGGGAGATCTGAATTC-3) $(19,20)$ primers by PCR. To improve specificity, we performed the second PCR with $1 \mu$ l of PCR product and the nested primer pair, IP-3 (5- ${ }^{49}$ GATATTTGGGGCTCATGGTCATTGT $^{25}$-3) and L3 (5-GACCCGGGAGATCTGAATTCAATTC-3). After the amplification procedure, one fifth of the amplified DNA was separated on $4.0 \%$ NuSieve agarose gel and visualized by ethidium bromide staining. The separated DNA was extracted from the gel and subcloned into pUC 18 vector. The cloned DNA was sequenced by the dideoxynucleotide method.

Comparison of tax gene expression levels of SCCs-I and III. To examine the relationship of tax expression to synovial cell proliferation, we compared the level of tax gene expression between SCCs-I and SCCs-III by reverse transcription (RT)-PCR analysis for tax mRNA (22). SCCs-I and -III were cultured in the presence or absence of $10 \%$ FCS. RT-PCR using RPX3 $\left(5-{ }^{5096}\right.$ ATCCCGTGGAGACTCCTC$\left.\mathrm{AA}^{5115}-3\right)$ and PRX4 (5- ${ }^{7357}$ AACACGTAGACTGGGTATCC $\left.{ }^{7338}-3\right)$ specific for HTLV-I taxl / rexl (GeneBank accession no. J02029) was performed as described (22).

In vitro transfection analysis of the tax expressing plasmid into $S C C s-I V$. The in vitro transfection assay was carried out with the following plasmids: the tax expression plasmid $\mathrm{pH} 2 \mathrm{R} 40 \mathrm{M}$ driven by the SV40 early promoter, and the $\mathrm{pH} 2 \mathrm{R}$ neo plasmids containing a bacterial neomycin resistance gene alone (23-25). $3 \mu \mathrm{g}$ of plasmid preparation were coprecipitated in calcium phosphate solution and added to the cells $\left(1 \times 10^{5}\right.$ cells per 60 -mm culture dish $)$. After $6 \mathrm{~h}$, the cells were glycerol shocked, washed, and recultured in HAM F- 12 medium for 48 h. At this point, G418 selection $(500 \mu \mathrm{g} / \mathrm{ml}$ ) was initiated. After $14 \mathrm{~d}$ of selection, individual G418-resistant clones were replated onto 96-well culture plates ( 0.5 cells per well) and cultured to confluency. Expression of $c$-fos, IL- $1 \beta$ and IL- 6 mRNA were examined by the RT-PCR method.

\section{Results}

Establishment of non-T cell synovial cell clones and detection of HTLV-I proviral DNA. We established $131 \mathrm{SCC}$ from a patient with HAAP by means of a limiting dilution culture of up to $60 \mathrm{~d}$. As shown in Fig. 1, the SCCs were classified into four types (I-IV). Of these four, type I ( 31 clones) and type III (27 clones) carried proviral HTLV-I DNA. In total, 58 SCCs had the HTLV-I genome. Since we dispensed the cells at a concentration of 0.5 cells per well into four 96 -well plates, 192 


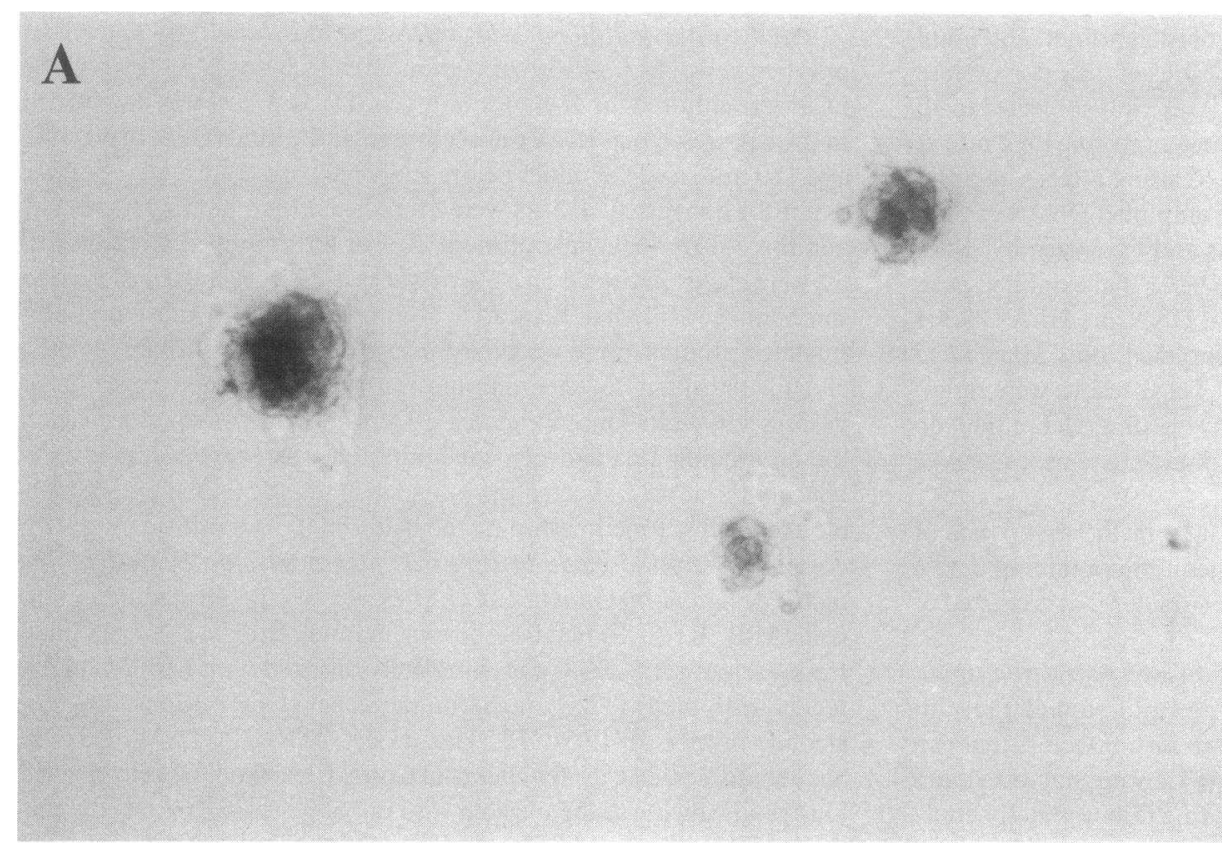

B

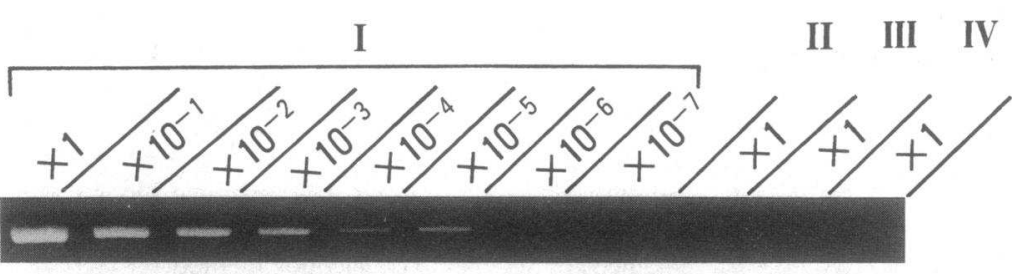

c-fos

IL-1 $\beta \longrightarrow$

IL- 6

$\beta-\operatorname{actin}$

Figure 2. Comparison of the proliferative capacity among the individual SCCs (I-IV) determined under the following two conditions. $(A)$ Colony formation assays performed in semisolid agarose. 1,000 cells were cultured for 14 $\mathrm{d}$ in medium containing $0.33 \%$ agarose. After this period, colonies were counted under light microscopy and photomicrographed $(\times 25)$. $(B)$ Expression of $c$-fos, IL- $1 \beta$, and IL-6 mRNA were determined under starvation condition by RT-PCR analysis. 10-fold titrated RNA (20 pg-200 ng) from the four SCC types was converted to CDNA and then analyzed by RT-PCR. I, II, III, and IV are the four types of SCCs.

cells were theoretically present. It followed from these data that at least $30.2 \%$ of synovial cells in the affected joint had proviral HTLV-I DNA ( 58 integrated SCCs/ 0.5 cells per well $\times 96$ wells $\times 4$ plates). 31 of 58 HTLV-I provirus-carrying SCCs
(53.4\%) reached confluency within $60 \mathrm{~d}$. In contrast, $97.8 \%$ of HTLV-I uninfected SCCs (72/73 SCCs) failed to reach confluency as compared with $46.6 \%$ of the integrated SCCs. In addition, $20.0 \%$ and $25.8 \%$, respectively, of the SCCs of two

Table I. Comparison of SCC Growth Capacities

\begin{tabular}{|c|c|c|c|c|c|c|c|c|}
\hline & \multirow[b]{2}{*}{ No. of clones } & \multirow[b]{2}{*}{ Proliferation } & \multirow{2}{*}{$\begin{array}{c}\text { HTLV-I } \\
\text { provirus DNA }\end{array}$} & \multirow[b]{2}{*}{ Colony formation } & \multirow[b]{2}{*}{$\operatorname{tax} / \mathrm{rex}$} & \multicolumn{3}{|c|}{ Expression of } \\
\hline & & & & & & $c-f o s$ & IL- $1 \beta$ & IL-6 \\
\hline SCCs-I & 31 & $\mathrm{C}$ & + & $3.18 \pm 0.55$ & ++ & ++++ & +++ & +++ \\
\hline SCC-II & 1 & $\mathrm{C}$ & - & $0.04 \pm 0.02$ & N.T. & - & - & - \\
\hline SCCs-III & 27 & $\mathbf{U}$ & + & 0 & - & - & - & - \\
\hline SCCs-IV & 72 & $\mathbf{U}$ & - & 0 & N.T. & - & - & - \\
\hline \multicolumn{9}{|c|}{ Transfectant with } \\
\hline pH2Rneo & & $\mathbf{U}$ & & N.T. & - & - & - & - \\
\hline $\mathrm{pH} 2 \mathrm{R} 40 \mathrm{M}$ & & $\mathrm{C}$ & & N.T. & +++ & +++ & +++ & +++ \\
\hline
\end{tabular}

The products amplified by TR-PCR can be detected from RNA in amounts indicated by the symbols:,$+ 20-200 \mathrm{ng} ;++, 200 \mathrm{pg}-2.0 \mathrm{ng} ;+++$, 2.0-20 pg; -, not detected. Abbreviations: C, confluent SCCs; N.T., not tested; U, unconfluent SCCs. 

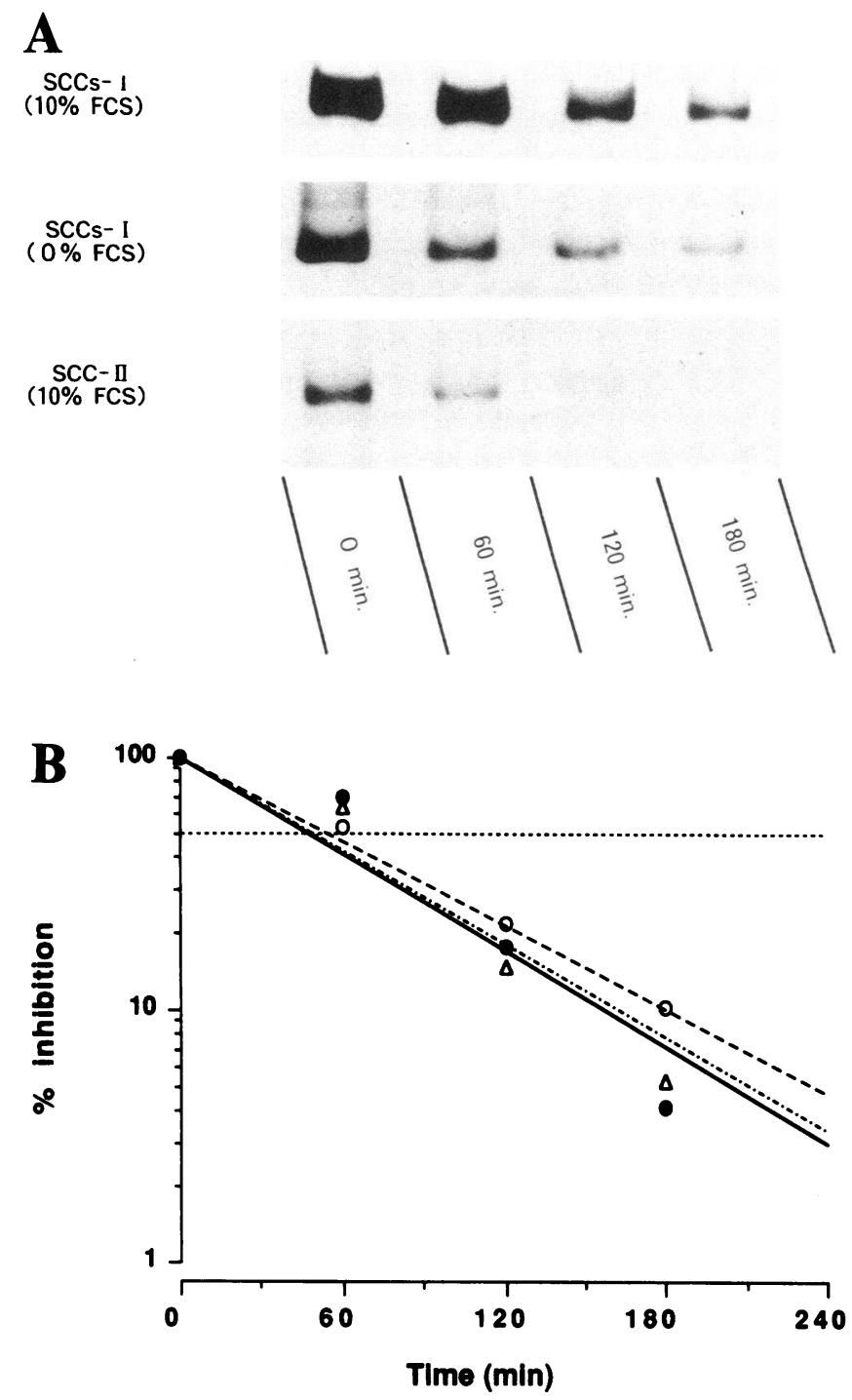

Figure 3. Study of the half-life of $c$-fos mRNA in SCCs by actinomycin-D treatment. Total RNA was recovered at intervals of $0,60,120$, and $180 \mathrm{~min}$. SCCs-I with and without $10 \%$ FCS and SCCs-II with $10 \%$ FCS were cultured for $48 \mathrm{~h}$. $(A)$ Biotinylated RT-PCR amplified products were visualized using the streptavidin/biotinylated alkaline phosphatase/chemiluminescent substrate system. $(B)$ Percent inhibition is (absorbance units at the indicated time divided by that at 0 time) $\times 100$ and this was plotted against time to estimate the half-life of $c$-fos mRNA. The bracketed symbols indicate SCCs-I with $10 \%$ FCS $(0, r=-0.9880)$ or without FCS $(\Delta, r=-0.9790)$ and SCC-II with $10 \%$ FCS $(\bullet, r=-0.9824)$.

other patients with HAAP carried HTLV-I proviral DNA. Therefore, integration of HTLV-I appears to be closely linked to the altered growth pattern of the SCCs.

Colony formation assay. We performed the colony formation assay to assess the anchorage-independent growth capacity and altered growth characteristics. We found that $3.18 \pm 0.55 \%$ of SCCs-I formed colonies (Fig. $2 A$ ). However, only $0.04 \pm 0.02 \%$ of SCC-II were capable of forming colonies. Colony formation was not observed with SCCs-III- and -IV.

Detection of $c-f o s, I L-1 \beta$, and IL-6 $m R N A$ under starvation conditions. As shown in Fig. $2 B$, the four kinds of SCCs yielded nearly the same amount of amplified mRNA for $\beta$-actin. In spite of starvation conditions, SCCs-I continued to grow and the amplified signal from $c$-fos mRNA was obtained even from $10^{-5}$ diluted $(20 \mathrm{pg})$ mRNA. The mRNAs of IL- $1 \beta$ and IL-6 were also detected only in SCCs-I (Fig. $2 B$ and Table I).

Study of the half-life of $c$-fos $m R N A$ in individual SCCs. To search out a possible mechanism for potentiated $c$-fos mRNA expression, we determined the half-life of $c$-fos mRNA expression in each type of SCC. As shown in Fig. 3, the half-life was 52 min for SCCs-I under serum-free conditions. In the presence of $10 \%$ FCS, the half-lives for SCCs-I and -II were 51 and $58 \mathrm{~min}$, respectively. It is possible that $c$-fos mRNA was transcriptionally activated rather than posttranscriptionally stabilized in SCCs-I. Furthermore, those of IL- $1 \beta$ and IL- 6 were also found to be transcriptionally activated (data not shown).

Analysis of the mode of HTLV-I integration into SCCS-I by the $L M-P C R$. Next, we determined the manner of integration of HTLV-I into SCCs using the modified LM-PCR to assess the clonality of SCCs-I. We found that the sizes of the amplified DNA products from six SCCs-I (Fig. 4, top) and those of PCR
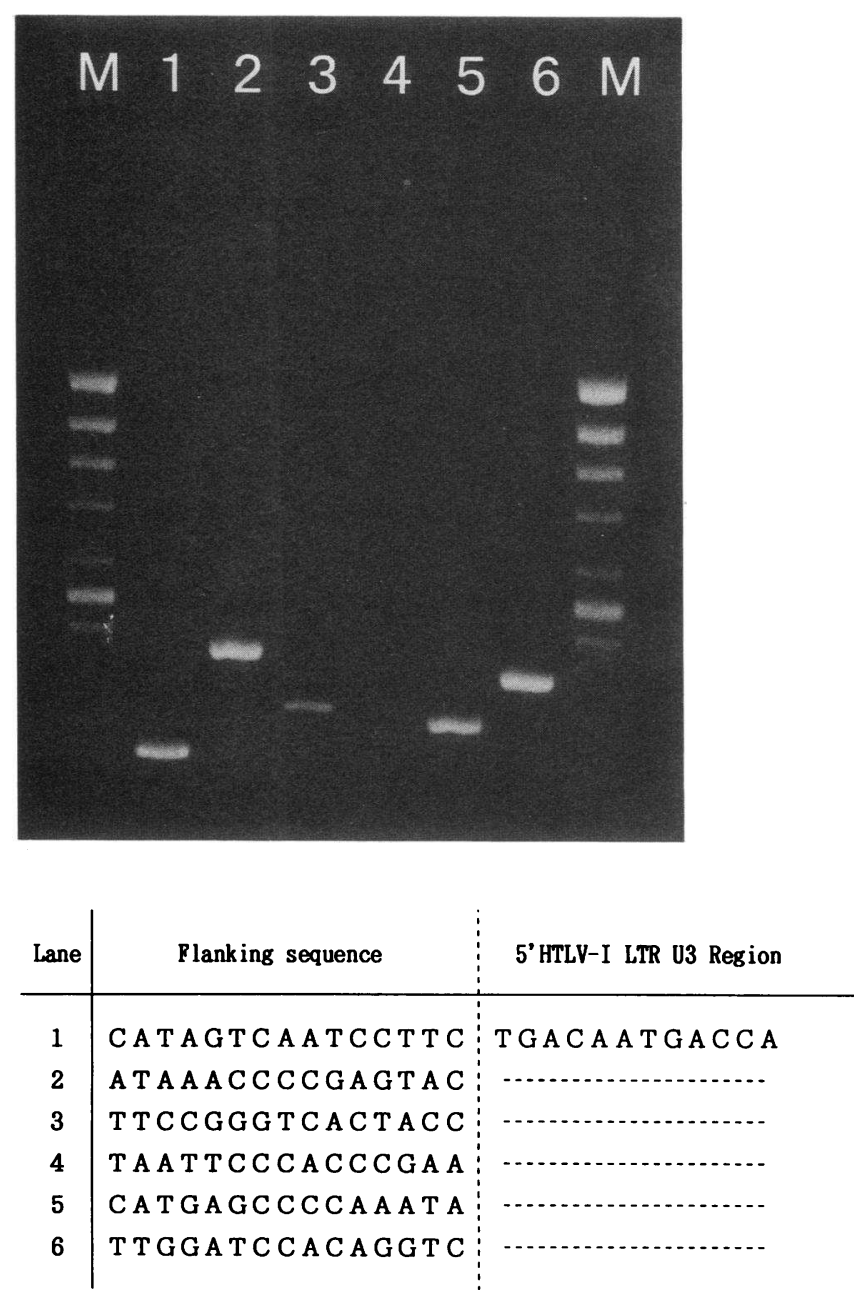

Figure 4. Determination of the mode of HTLV-I integration into SCCs by modified LM-PCR analysis. (Top). Ethidium bromide staining of LM-PCR products from individual SCCs-I. LM-PCR was performed using EcoRI-digested DNA of individual SCC-I. M, DNA molecular weight marker ( $\Phi$ X174/Hinc II digestion); lanes 1-6, individual SCCs-I. (Bottom). Nucleotide sequence of adjoining 5'HTLV-I LTR from individual SCCs-I. Lanes 1-6, individual SCCs-I. 
products representing sequences adjoining the $5^{\prime} \mathrm{HTLV}$-I LTR U3 region were substantially different from one to another (Fig. 4, bottom). These results indicate that most SCCs that had randomly integrated the HTLV-I genome were oligo- to polyclonal populations. These data suggest that HTLV-I did not act as a cis-element by site-specific integration, but acted in trans to promote synovial cell proliferation.

Comparison of tax gene expression levels of SCCs-I and III. Taken together, all of our current observations demonstrate that an HTLV-I-encoded protein acts as a transcriptional trans-activator in synovial cells. In this sense, the tax gene in the HTLV-I genome (26) is believed to function as a transcriptional trans-activator. Therefore, we compared the expression level of the tax gene in SCCs-I and -III. As shown in Fig. 5, tax transcripts were detected in SCCs-I but not in SCC-III.

In vitro transfection analysis of the tax expressing plasmid into SCCs-IV. As shown in Table I, tax-expressing transfectants reached confluency within $37.4 \pm 2.8 \mathrm{~d}$ and $c$-fos, IL- $1 \beta$, and IL-6 mRNAs were transactivated (Table I and data not shown).

\section{Discussion}

Recent studies have shown the existence of a large number of HTLV-I proviral copies in PBMCs of TSP/HAM (27-29), and it is speculated that this significant viral load may play an important role in the pathogenesis of TSP/HAM. In addition, Kira et al. (29) reported that almost the same level of proviral load observed in TSP/HAM exists in PBMCs of HTLV-I carriers without TSP/HAM who suffered from autoimmune or inflammatory diseases. However, semiquantitative PCR analysis (29) showed that the proviral load of PBMCs derived from the three patients in this study was about $0.2-0.05 \%$ (data not shown). Nevertheless, we found that SCCs from patients with HAAP exhibited HTLV-I integration with high frequency, $30.2 \%, 20.0 \%$, and $25.6 \%$, respectively. Moreover, $53.4 \%$ of integrated-SCCs developed to confluency within $60 \mathrm{~d}$, whereas only $2.6 \%$ of nonintegrated SCCs reached confluency under the same conditions. Therefore, these findings suggest that integration by HTLV-I into synovial cells leads to acquisition of a higher proliferative capacity. Accordingly, we compared the proliferative capacity of individual SCCs under the following conditions.

First, we cultured SCCs under semisolid conditions to assess anchorage-independent growth ability. We found that
SCCs-I were capable of forming colonies at a higher rate than other types of SCCs. These data revealed that SCCs-I acquired the potential for autonomous proliferation. In addition, in spite of starvation conditions, SCCs-I were able to grow and $c-f o s$, IL- $1 \beta$, and IL- 6 mRNA were overexpressed in these cells. In particular, $c$-fos protooncogene is induced upon entry into the proliferative cycle in a wide variety of cells (30-37) and can be considered as a "universal" activation gene (38). In addition, it is induced by $\mathrm{p} 40^{\text {tax }}$ through the cAMP-responding element-binding protein/activating transforming factor (CREB/ ATF) pathway $(39,40)$. It may, therefore, be that overexpression of $c$-fos mRNA in integrated SCCs can account for enhanced cell proliferation through the CREB/ATF pathway. With respect to the overexpression of IL- $1 \beta$ and IL-6, we have already reported that these inflammatory cytokines are constitutively produced in rheumatoid synovial cells and tightly associated with synovial cell proliferation in RA (15, 41-43). Therefore, it is possible that SCCs-I are not only able to grow autonomously but can also enhance the proliferation of other types of synovial cells through the paracrine pathway.

Nevertheless, it is still possible that the detected proviral DNA may result from in vitro transmission from HTLV-I-infected $\mathrm{T}$ cells or synovial cells during the cloning procedure. We have previously shown, however, that HTLV-I transmissibility to synovial cells was very low during a 12-d culture period (13). It is, therefore, unlikely that this proviral DNA may be attributed to in vitro transmission of HTLV-I. So far, it appears that the integration by HTLV-I plays an important role in promoting synovial cell proliferation in patients with HAAP and it may be that the high frequency of SCCs carrying proviral HTLV-I DNA in affected joints is a reflection of this higher proliferative capacity.

To clarify the mechanism of overexpression of these mRNAs, we determined their half-lives by treatment with actinomycin-D. The degradation rates of these mRNAs were not significantly different between SCCs-I and -II. Thus, these mRNAs were likely to be transcriptionally activated in SCCs-I. Transcriptional activation of these mRNAs was observed only in SCCs-I. These observations suggest that an HTLV-I-encoded protein might function as a transcriptional activator in synovial cells.

We also analyzed the manner of integration of HTLV-I into individual SCCs-I and determined their clonality. For this purpose, Southern blot analysis (44) has usually been applied (45). However, the amount of DNA obtained from the SCCs

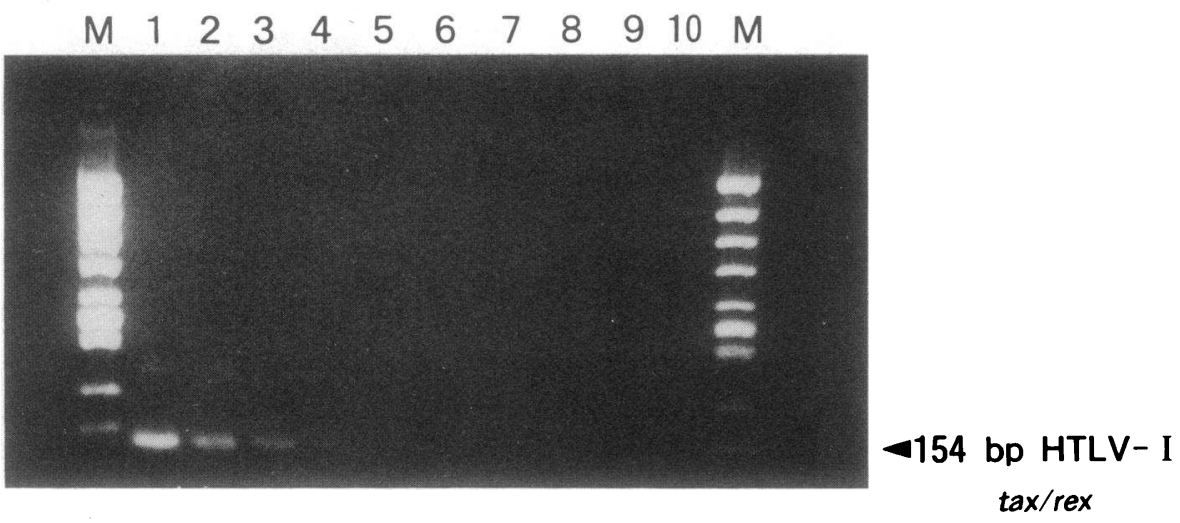

Figure 5. Comparison of tax gene expression between SCCs-I and SCCs-III. Detection of tax/rex mRNA under starvation conditions by RT-PCR analysis. 10-fold titrated RNA ( $20 \mathrm{pg}-200 \mathrm{ng}$ ) from the four kinds of SCCs were converted to CDNA and submitted to RT-PCR. Lanes 1-8, 10fold titrated cDNA from SCCs-I $(\times 1$ to $\times 10^{-7}$ ) without FCS; lane 9, cDNA from SCCs-III with $10 \%$ FCS; lane 10, cDNA from SCCs-III without FCS. Amplification conditions were as described $(13,22)$. 
was too small to be analyzed by Southern blot hybridization. We carried out the modified LM-PCR and were able to determine the unknown sequence adjoining the 5' HTLV-I LTR region using $<10 \mathrm{ng}$ of genomic DNA. In ATL, monoclonal genomic integration of proviral HTLV-I DNA has been demonstrated by Southern blot analysis (45). On the other hand, we found that proviral HTLV-I DNA appeared to be randomly integrated into six representative SCCs-I that were obtained from the same HAAP patient. These results indicate that oligoor polyclonal HTLV-I integrated synovial cells proliferate in the affected synovium of patients with HAAP. In that these SCCs-I had almost the same proliferative capacity and exhibited a random manner of integration, we conclude that HTLVI might act as a trans-activator rather than as a promoter of cis-activation of cellular genes by site-specific integration into synovial cells.

The study of half-lives of three kinds of mRNAs and the mode of HTLV-I integration also suggest that HTLV-I works as a transcriptional trans-activator. However, there is fairly general agreement that six or more kinds of protein are encoded in the HTLV-I genome $(46,47)$. One of these, $\mathrm{p} 40^{\operatorname{tax}}$ is well known as a transcriptional trans-activator (26). We have already reported that HTLV-I tax/rex mRNA could be detected in fresh synovial tissue and cultured $T$ cell-depleted synovial cells but not in circulating fresh peripheral blood mononuclear cells or in fresh synovial fluid cells of HAAP patients (13). Furthermore, $\operatorname{tax}$ mRNA was preferentially expressed in the synovium of transgenic mice that carried the HTLV-I genome and exhibited synovial overgrowth resembling that seen in RA (14). Thus, it is speculated that $\mathrm{p} 40^{\text {tax }}$ works to promote synovial cell proliferation in patients with HAAP. To provide further evidence to support this speculation, we compared the expression level of the tax gene between SCCs-I and -III. Although SCCs-III carried proviral HTLV-I DNA as did SCCs-I, SCCs-III had neither an enhanced growth ability nor detectable $\operatorname{tax}$ mRNA. Further study are required to explain why tax mRNA could be detected in SCCs-I but not in SCCs-III. Our observation, however, suggests that $\mathrm{p} 40^{\text {tax }}$, acting as a transcriptional trans-activator, plays a central role in the acquisition of enhanced growth capacity in synovial cells.

For greater understanding of the role of the $\operatorname{tax}$ gene in synovial cells, we carried out in vitro transfection of SCCs-IV, which are nonintegrated and unconfluent SCCs. We found that tax-expressing transfectants were capable of growing factor and developing to confluency. In addition, mRNAs for $c$-fos, IL$1 \beta$, and IL- 6 appeared to be transcriptionally trans-activated. Based on our observation, the HTLV-I tax gene likely causes the synovial cell proliferation observed in patients with HAAP.

It has previously been demonstrated that products of the tax gene are able to trans-activate not only the viral LTR (26, 48-51) but also many specific cellular genes. The Tax protein has been shown to activate transcription of the genes for IL-2 (52-54), the $\alpha$ chain of IL-2 receptor (IL-2R $\alpha$ ) (55-58), graulocyte-macrophage colony-stimulating factor (59-62), nerve growth factor (NGF) (63), vimentine (64), and $c$-fos protooncogene (39). In $\mathrm{CD}^{+} \mathrm{T}$ lymphocytes, it has been postulated that the tax gene plays an important role in leukemogenesis through the IL-2/IL-2R $\alpha$ autocrine pathway $(65,66)$. Furthermore, activation of NF- $\kappa \mathrm{B} /$ Rel likely is involved in leukemogenesis, since Tax trans-activation of the genes for both IL-2 and IL-2R $\alpha$ requires induction of NF- $\kappa \mathrm{B} / \operatorname{Rel}(54,55,57,58)$.
Also, Grassmann et al. $(57,58)$ reported that tax function is essential and sufficient in itself for immortalization of primary human $\mathrm{CD}^{+}{ }^{+}$cord blood lymphocytes in culture in the context of the herpesvirus saimiri vector. Recently, several lines of evidence suggest that the tax gene may involve nonlymphoid cell proliferation. Overexpression of the tax gene in several rodent fibroblast cell lines leads to transformation of these cells (25) and coexpression of the tax gene with the ras oncogene transforms primary rat fibroblasts (69). Furthermore, Smith and Greene (40) reported that transcriptional activation through the CREB/ATF pathway may play an important role in these Tax-mediated cellular transformations. Moreover, tax gene expression causes mesenchymal tumors (70), neurofibromatosis (71), and synovial overgrowth (14) in various transgenic mouse models. Green (63) speculated that Tax activation of the NGF/NGF receptor autocrine pathway may be involve in the development of neurofibromatosis in transgenic mice. In this report, we found that HTLV-I tax is responsible for the growth of synovial cells in humans. Further investigation is required to determine how the tax gene triggers synovial cell proliferation. This is, however, the first report that clearly describes a biological function for the $\operatorname{tax}$ gene in nonlymphoid cell proliferation in humans. We therefore believe that these findings may lead to a deeper understanding of not only this novel biological function of the HTLV-I tax gene but also of the pathogenesis of HTLV-I-associated diseases.

\section{Acknowledgments}

We thank Drs. M. Ziff, A. M. Krieg, H. Mitsuya, C. Morimoto, M. Osame, and Y. Mizushima for helpful discussion and criticisms of this manuscript, and T. Abe for his technical assistance.

This work was supported in part by grants for general scientific research of the Ministry of Education, Science and Culture of Japan, the Ministry of Welfare, and the Japan Rheumatism Foundation.

\section{References}

1. Poiesz, B. J., F. W. Ruscetti, A. F. Gazdar, P. A. Bunn, J. D. Minna, and R. C. Gallo. 1980. Detection and isolation of type C retrovirus particles from fresh and cultured lymphocytes of a patient with cutaneous T-cell lymphoma. Proc. Natl. Acad. Sci. USA. 77:7415-7419.

2. Hinuma, Y., K. Nagata, M. Hanaoka, M. Nakai, T. Matsumoto, S. Kinoshita, S. Shirakawa, and I. Miyoshi. 1981. Adult T-cell leukemia:antigen in an ATL cell line and detection of antibodies to the antigen in human sera. Proc. Natl. Acad. Sci. USA. 78:6476-6480.

3. Uchiyama, T., J. Yodoi, K. Sagawa, K. Takatsuki, and H. Uchino. 1977. Adult T-cell leukemia:clinical and hematologic features of 16 cases. Blood. 50:481-492.

4. Yoshida, M., I. Miyoshi, and Y. Hinuma. 1982. Isolation and characterization of retrovirus from cell line of human adult T-cell leukemia and its implication in the disease. Proc. Natl. Acad. Sci. USA. 79:2031-2035.

5. Gessin, A., F. Brain, J. C. Vernant, O. Gout, L. Maurs, and A. G. Calender. 1985. Antibodies to human T-lymphotropic virus type-I in patients with tropical spastic paraparesis. Lancet. ii:407-410.

6. Osame, M., K. Usuku, S. Izumo, N. Ijicji, H. Amitani, A. Igata, M. Matsumoto, and M. Tara. 1986. HTLV-I associated myelopathy, a new clinical entity. Lancet. $i: 1031-1032$.

7. Harden, E. A., J. O. Moore, and B. F. Haynes. 1984. Leukemia-associated arthritis: identification of leukemia cells in synovial fluid using monoclonal and polyclonal antibodies. Arthritis Rheum. 27:1306-1308.

8. Taniguchi, Y. Takenaka, Y. Noda, Y. Ueno, K. Shitikawa, K. Sato, N. Miyasaka, and K. Nishioka. 1988. Adult T-cell leukemia presenting with proliferative synovitis. Arthritis Rheum. 31:1076-1077.

9. Kitajima, I., I. Maruyama, Y. Maruyama, S. Ijichi, N. Eiraku, Y. Mimura, and M. Osame. 1989. Polyarthritis in human T lymphotropic virus type-I associated myelopathy. Arthritis Rheum. 32:1342-1344.

10. Nishioka, K., I. Maruyama, K. Sato, I. Kitajima, Y. Nakajima, and M. 
Osame. 1989. Chronic inflammatory arthropathy associated with HTLV-I. Lancet. $i: 441$.

11. Sato, K., I. Maruyama, Y. Maruyama, I. Kitajima, Y. Nakajima, M. Higaki, K. Yamamoto, N. Miyasaka, M. Osame, and K. Nishioka. 1991. Arthritis in patients infected with human T lymphotropic virus type I. Arthritis Rheum. 34:714-721.

12. Sato, K., I. Maruyama, and K. Nishioka. 1992. HTLV-I and arthritis. Rheumatol. Rev. 1:185-192.

13. Kitajima, I. K. Yamamoto, K. Sato, Y. Nakajima, T. Nakajima, I. Maruyama, M. Osame, and K. Nishioka. 1991. Detection of human T cell lymphotropic virus type I proviral DNA and its gene expression in synovial cells in chronic inflammatory arthropathy. J. Clin. Invest. 88:1315-1322.

14. Iwakura, Y., M. Tosu, E. Yoshida, M. Takiguhi, K. Sato, I. Kitajima, K. Nishioka, K. Yamamoto, T. Takeda, M. Hatanaka, et al. 1991. Induction of inflammatory arthropathy resembling rheumatoid arthritis in mice transgenic for HTLV-I. Science (Wash. DC). 253:1026-1028.

15. Goto, M., M. Sasano, H. Yamanaka, N. Miyasaka, N. Kamatani, K. Inoue, K. Nishioka, and T. Miyamoto. 1987. Spontaneous production of an interleukin 1-like factor by cloned rheumatoid synovial cells in long-term culture. J. Clin. Invest. 80:786-796.

16. Saiki, R. K., D. H. Elefand, S. Stoffel, S. J. Scharf, R. Higuchi, G. T. Horn, K. B. Mullis, and H. A. Erlich. 1987. Primer-directed enzymatic amplification of DNA with a thermostable DNA polymerase. Science (Wash. DC). 239:487-491.

17. Kwok, S., G. Ehrlich, B. Poietz, R. Kalish, and J. J. Sninsky. 1988. Enzymatic amplification of HTLV-I viral sequences from peripheral blood mononuclear cells and infected tissues. Blood. 72:117-1123.

18. Scharf, S. J., C. M. Long, and H. A. Erlich. 1988. Sequence analysis of the HLA-DQ and HLA-DQ loci from three pemphigus vulgaris patients. Hum. Immunol. 22:61-69.

19. Chomczynski, P., and N. Sacch. 1987. Single-step method of RNA isolation by acid guanidinium thiocyanate-phenol-chloroform extraction. Anal. Biochem. 162:156-159.

20. Pfeiffer, G. P., S. D. Steigerwald, P. M. Mueller, B. Wol, and A. D. Riggs R. 1989. Genomic sequencing and methylation analysis by ligation mediated PCR. Science (Wash. DC). 227:810-813.

21. Mueller, P. R., and B. Wold. 1989. In vivo footprinting of a muscle specific enhancer by ligation mediated PCR. Science (Wash. DC). 246:780-786.

22. Kinoshita, T., M. Shimoyama, K. Tobinai, M. Ito, S. Ito, S. Ikeda, K. Tajima, K. Shimotohno, and T. Sugiura. 1989. Detection of mRNA for the $\operatorname{tax} 1 /$ rex 1 gene of human $T$-cell leukemia virus type $I$ in fresh peripheral blood mononuclear cells of adult T-cell leukemia patients and viral carriers by using the polymerase chain reaction. Proc. Natl. Acad. Sci. USA. 86:5620-5624.

23. Mori, K., H. Sabe, H. Simoi, T. Iino, A. Tanaka, K. Takeuchi, K. Hirayoshi, and M. Hatanaka. 1987. Expression of a provirus of human T cell leukemia virus type I by DNA transfection. J. Gen. Virol. 68:499-506.

24. Miyazaki, Y., T. Takamatsu, T. Nosaka, S. Fujita, and M. Hatanaka. 1992. Intracellular topological distribution of HIV-1 trans-activators. FEBS (Fed. Eur. Biochem. Soc.) Lett. 305:1-5.

25. Tanaka, A., C. Takahashi, S. Yamaoka, T. Nosaka, M. Maki, and S. Hatanaka. 1990. Oncogenic transformation by the tax gene of human T-cell leukemia virus type I in vitro. Proc. Natl. Acad. Sci. USA. 87:1071-1075.

26. Seiki, M., J. Inoue, T. Takedsa, and M. Yoshida. 1986. Direct evidence and $\mathrm{p} 40^{\mathrm{x}}$ of human $\mathrm{T}$-cell leukemia virus type is a trans-acting transcriptional activator. EMBO (Eur. Mol. Biol. Organ.) J. 5:561-565.

27. Yoshida, M., M. Osame, H. Kawai, M. Toita, N. Kuwasaki, Y. Nishida, Y. Hiraki, K. Takahashi, K. Nomura, S. Sonoda, et al. 1989. Increased replication of HTLV-I in HTLV-I-associated myelopathy. Ann. Neurol. 26:331-335.

28. Gessain, A., F. Saal, O. Gout, M.-T. Daniel, G. Flandrin, G. de The, J. Peries, and F. Sigaux. 1990. High human T-cell lymphotropic virus type I proviral DNA load with polyclonal integration in peripheral blood mononuclear cells of French West Indian, Guianese, and African patients with tropical spastic paraparesis. Blood. 75:428-433.

29. Kira, J., Y. Koyanagi, T. Yamada, Y. Itoyama, I. Goto, N. Yamamoto, H. Sasaki, and Y. Sasaki. 1991. Increased HTLV-I proviral DNA in HTLV-I-associated myelopathy: A quantitative polymerase chain reaction study. Ann. Neurol. 29:194-201.

30. Greenberg, M. E., and E. B. Ziff. 1984. Stimulation of 3 T3 cells induces transcription of the c-fos proto-oncogene. Nature (Lond.). 311:433-438.

31. Collart, M. A., D. Felin, C. Briottet, B. Thorens, J. D. Vassalli, and P. Vassalli. 1989. Receptor-mediated phagocytosis by macrophages induces a calcium-dependent transient increase in c-fos transcription. Oncogene. 4:237-241.

32. Prywes, R., and R. G. Roeder. 1986. Inducible binding of a factor to the c-fos enhancer. Cell. 47:777-784.

33. Shaw, P. E., H. Schroeter, and A. Nordheim. 1989. The ability of a ternary complex to form over the serum response element correlates with serum inducibility of the human $c$-fos promoter. Cell. 56:563-572.

34. Grausz, J. D., D. Fradelizi, F. Dautry, R. Monier, and P. Lehn. 1986.
Modulation of c-fos and c-myc mRNA levels in normal human lymphocytes by calcium ionophore A23187 and phorbol ester. Eur. J. Immunol. 16:1217-1221.

35. Visvader, J., P. Sassone-Corsi, and I. M. Verma. 1988. Two adjacent promoter elements mediate nerve growth factor activation of the c-fos gene and bind distinct nuclear complexes. Proc. Natl. Acad. Sci. USA. 85:9474-9478.

36. Fisch, T. M., R. Prywes, and R. G. Roeder. 1987. c-fos sequences necessary for basal expression and induction by epidermal growth factor, 12-O-tetradecanoyl phorbol-13-acetate, and the calcium ionophore. Mol. Cell. Biol. 7:3490-3502.

37. Trouche, D., P. Robin, O. Robillard, P. Sassone-Corsi, and Harel-Bellan. 1991. c-fos transcriptional activation by IL-2 in mouse CTL-L2 cells is mediated thorough two distinct signal transduction pathways converting on the same enhancer element. J. Immunol. 147:2398-2403.

38. Marx, J. L. 1987. The fos gene as "Master Switch." Science (Wash. DC) 237:854-855.

39. Fujii, M., P. Saaaone-Corsi, and I. M. Verma. 1988. c-fos promoter transactivation by the tax 1 protein of human T-cell leukemia virus type I. Proc. Natl. Acad. Sci. USA. 85:8526-8530.

40. Smith, M. R., and W. C. Green. 1991. Type I human T cell leukemia virus tax protein transforms rat fibroblasts through the cyclic adenosine monophosphate response element binding protein/activating transcription factor pathway. J. Clin. Invest. 88:1038-1042.

41. Miyasaka, N., K. Sato, M. Goto, M. Sasano, M. Matsuyama, K. Inoue, and K. Nishioka. 1988. Augmented interleukin-1 producion and HLA-DR expression in the synovium of rheumatoid arthritis patients. Arthritis Rheum. 31:480-486.

42. Miyasaka, N., K. Sato, J. Hashimoto, H. Kohsaka, K. Yamamoto, M. Goto, K. Inoue, T. Hirano, T. Kishimoto, and K. Nishioka. 1989. Constitutive production of interleukin 6/B cell stimulately factor- 2 from inflammatory synovium. Clin. Immunol. Immunopathol. 52:238-247.

43. Bucala, R., C. Ritchlin, R. Winchester, and A. Cerami. 1991. Constitutive production of inflammatory and mitogenic cytokines by rheumatoid synovial fibroblasts. J. Exp. Med. 173:569-578.

44. Southern, E. M. 1975. Detection of specific sequence among DNA fragments separated by gel electrophoresis. J. Mol. Biol. 98:503-517.

45. Yoshida, M., M. Seiki, K. Yamaguchi, and K. Takatsuki. 1984. Monoclonal integration of human T-cell leukemia provirus in all primary tumors of adult disease. Proc. Natl. Acad. Sci. USA. 81:2534-2537.

46. Seiki, M., S. Hattori, Y. Hirayama, and M. Yoshida. 1983. Human adult T-cell leukemia virus: complete nucleotide sequence of the provirus genome integrated in leukemia cell DNA. Proc. Natl. Acad. Sci. USA. 80:3618-3622.

47. Ciminale, V., G. N. Pavlakins, D. Derse, C. P. Cunningham, and B. K. Felber. 1992. Complex splicing in the human T-cell leukemia virus (HTLV) family of retroviruses: novel mRNAs and proteins produced by HTLV type I. $J$. Virol. 66:1737-1745.

48. Felber, B., H. Paskalis, C. Kleinman-Ewing, F. Wong-Staal, and G. N. Pavlakins. 1985. The $\mathrm{pX}$ protein of HTLV-I is a transcriptional activator of its long terminal repeats. Science (Wash. DC). 229:675-679.

49. Fujisawa, J., M. Seiki, M. Sato, and M. Yoshida. 1986. A transcriptional enhancer sequence of HTLV-I is responsible for trans-activation mediated by p40 of HTLV-I. EMBO (Eur. Mol. Biol. Organ.) J. 5:713-718.

50. Inoue, J., M. Yoshida, and M. Seiki. 1987. Transcriptional (p40) and post-transcriptional ( $\mathrm{p} 27^{\mathrm{x}}$-III ) regulators are required for the expression and replication of human T-cell leukemia virus type I genes. Proc. Natl. Acad. Sci. USA 84:3653-3657.

51. Sodroski, J., C. Rosen, W. C. Goh, and W. Haseltine. 1985. A transcriptional activator protein encoded by the $\mathrm{x}$-lor region of the human T-cell leukemia virus. Science (Wash. DC). 228:1430-1434.

52. Inoue, J., M. Seiki, T. Taniguchi, S. Tsuru, and M. Yoshida. 1986. Induction of interleukin- 2 receptor gene expression by $\mathrm{p} 40 \mathrm{x}$ encoded by human $\mathrm{T}$-cell leukemia virus type-I. EMBO (Eur. Mol. Biol. Organ.) J. 5:2883-2888.

53. Siekevitz, M., M. B. Feinberg, N. Holbrook, F. Wong-Staal, and W. C. Greene. 1987. Activation of interleukin 2 and interleukin 2 receptor (tac) promoter expression by the trans-activator ( $t a t)$ gene product of human T-cell leukemia virus, type I. Proc. Natl. Acad. Sci. USA. 84:5389-5393.

54. Hoyos, B., D. W. Ballard, E. B. Aniline, M. Siekevitz, and W. C. Greene 1989. Kappa B-specific DNA binding proteins: role in the regulation of human interleukin-2 gene expression. Science (Wash. DC). 244:457-460.

55. Ballard, D. W., E. Boehnlein, J. W. Lowenthal, Y. Wano, B. R. Fraza, and W. C. Greene. 1988. HTLV-I tax induces cellular proteins that activate the kB element in the IL-2 receptor $\alpha$ gene. Science (Wash. DC). 241:1652-1655.

56. Cross, S. L., M. B. Feinberg, J. B. Wolf, N. J. Holbrook, F. Wong-Staal, and W. J. Leonald. 1987. Regulation of the human interleukin-2 receptor $\alpha$ chain promoter:activation of a nonfunctional promoter by transactivator gene of HTLV-I. Cell. 49:47-56.

57. Leung, K., and G. J. Nabel. 1988. HTLV-I transactivator induces interleukin-2 receptor expression through an NF-kB-like factor. Nature (Lond.). 333:776-778. 
58. Ruben, S. M., H. Poteat, T.-H. Tan, K. Kawakami, R. Roeder, W. Haseltine, and C. A. Rosen. 1988. Cellular transcription factors and regulation of IL-2 receptor gene expression by HTLV-I tax gene product. Science (Wash. DC). 241:89-92.

59. Chan, J. Y., D. J. Salmon, S. D. Nimer, D. W. Golde, and J. C. Gasson. 1986. Regulation of expression of human granulocyte/macrophage colony stimulating factor. Proc. Natl. Acad. Sci. USA. 83:8669-8673.

60. Nimer, S. D., E. A. Morita, M. J. Martis, W. Wachsman, and J. C. Gasson. 1988. Characterization of the human granulocyte-macrophage colony-stimulating factor promoter region by genetic analysis: correlation with DNase I footprinting. Mol. Cell. Biol. 8:1979-1984.

61. Miyatake, S., M. Seiki, N. Yoshida, and K.-I. Arai. 1988. T-cell activation signals and human T-cell leukemia virus type I-encoded $p 40^{x}$ protein activate the mouse granulocyte-macrophage colony-stimulating factor gene through a common DNA element. Mol. Cell. Biol. 8:5581-5587.

62. Shannon, M. F., J. R. Gamble, and M. A. Vadas. 1988. Nuclear proteins interacting with promoter region of human granulocyte/macrophage colonystimulating factor gene. Proc. Natl. Acad. Sci. USA. 85:674-678.

63. Green, J. E. 1991. Trans activation of nerve growth factor in transgenic mice containing the human T-cell lymphotropic virus type I tax gene. Mol. Cell. Biol. 11:4635-4641.

64. Lilienbaum, A., M. Duc Dodon, C. Alexandre, L. Gazzolo, and D. Paulin. 1990. Effect of human T-cell leukemia virus type 1 tax protein on activation of the human vimentin gene. J. Virol. 64:256-263.
65. Sugamura, K., M. Fujii, T. Ishii, and Y. Hinuma. 1986. Possible role of interleukin 2 receptor in oncogenesis of HTLV-I/ATLV. Cancer Rev. 1:96-114.

66. Maruyama, M., H. Shibuya, H. Harada, M. Hatakeyama, M. Seiki, T. Fujita, J.-I. Inoue, M. Yoshida, and T. Taniguchi. 1987. Evidence for aberrant activation of interleukin- 2 autocrine loop by HTLV-1-encoded $\mathrm{p} 40^{x}$ and $\mathrm{t} 3 / \mathrm{Ti}$ complex triggering. Cell. 48:343-350.

67. Grassmann, R., C. Dengler, I. Muller-Feckelstein, B. Fleckenstein, K McGuire, M.-C. Dokheler, J. G. Sordroski, and W. A. Haseltine. 1989. Transformation to continuous growth of primary human T-lymphocytes by human T-cell leukemia virus type I X-region genes transducted by a herpesvirus saimiri vector. Proc. Natl. Acad. Sci. USA. 86:3351-3355.

68. Grassmann, R., S. Berchtold, I. Radant, M. Alt, B. Fleckenstein, J. G. Sordroski, W. A. Haseltine, and U. Ramstedt. 1992. Role of human T-cell leukemia virus type $1 \mathrm{X}$ region proteins in immortalization of primary human lymphocytes in culture. J. Virol. 66:4570-4575.

69. Pozzatti, R., J. Vogel, and G. Jay. 1990. The human T-lymphotropic virus type I tax gene can cooperate with the ras oncogene to induce neoplastic transformation of cells. Mol. Cell. Biol. 10:413-417.

70. Nerenberg, M., S. H. Hinrichs, R. K. Reynolds, G. Khoury, and G. Jay. 1987. The tat gene of human T lymphotropic virus type I induces mesenchymal tumors in transgenic mice. Science (Wash. DC). 237:1324-1329.

71. Hinrichs, S. H., M. Nerenberg, R. K. Reynolds, G. Khoury, and G. Jay. 1987. A transgenic mouse model for human neurofibromatosis. Science (Wash DC). 237:1340-1343. 